\title{
The preparedness of school community in facing tsunami disaster in Lhokseumawe City
}

\author{
Wheny Utariningsih ${ }^{1 *}$, Rizka Sofia ${ }^{1}$, Iffah Farhana Abu Talib ${ }^{2}$, and T. Saifullah ${ }^{3}$ \\ ${ }^{1}$ Medical Faculty of Malikussaleh University, Indonesia \\ ${ }^{2}$ U-INSPIRE Malaysia, Malaysia \\ ${ }^{3}$ Law Faculty of Malikussaleh University, Indonesia
}

\begin{abstract}
A tsunami in Aceh in 2004 resulted in many casualties and damage to educational facilities. The disaster taught about the importance of preparedness in anticipating disasters to humans. It will help in shaping and planning what actions need to be taken in the event of a disaster. This study aimed to see the level of preparedness of the school community in Lhokseumawe City in dealing with the tsunami disaster. School community preparedness was measured using preparedness parameters, namely knowledge, and attitudes; policies and guidelines; emergency response planning; disaster warning system; and resource mobilization. This research is descriptive quantitative research employing a survey method using a closed questionnaire. Utilizing the descriptive percentage method, the research shows that the school community's preparedness in Lhokseumawe City is in the almost ready category with an index value of 57.02. The index value is obtained by adding up the index values for each parameter by taking into account its weight. The index value of the knowledge and attitude parameter of the school community; and the level of school community policies and guidelines are in the ready category with index scores of 68,24 and 65 . School community emergency planning parameters; the level of the school community disaster warning system and the level of resource mobilization are in the unprepared category; not yet ready and almost ready with index values of 35.6 ; 40 ; and 54.15 respectively.
\end{abstract}

\section{Introduction}

The location of Aceh Province is at the confluence of two plates (Eurasia and Indo-Australia) which makes Aceh Province a high-risk area for earthquake disasters. This can be seen in the earthquake that was followed by the tsunami in 2004. Based on the Indonesian Disaster Data and Information, the disaster has resulted in 165,791 deaths and 2,830 injuries. 518,450 people had to evacuate from their homes and 179,312 houses were seriously damaged. As many as 240 health facilities and 1,226 educational facilities were also reported to be damaged [1].

The data states that thousands of educational facilities were damaged by the disaster. BAPPENAS [2] added that in the education sector it was estimated that 45,000 students and 1,870 teachers were missing, around 1,962 schools were damaged and destroyed and the loss was estimated at $\mathrm{Rp} 1041$ billion. The number of damaged educational facilities become a special concern for local governments as schools are a gathering place for students which makes them very vulnerable to disasters.

Communities, especially students who are dealing directly with disasters, are obliged to have preparedness in dealing with disasters. This will help in shaping and planning what actions need to be taken when a disaster occurs, especially a tsunami disaster. Preparedness in dealing with disasters is also very important for vulnerable groups, one of which is children. Reflecting on the 2004 tsunami which caused many educational facilities to be damaged, schools must be prepared in dealing with the tsunami disaster. This is because success in handling and evacuating students when a tsunami occurs is very dependent on the preparedness of the school itself.

Lhokseumawe is one of the cities in Aceh Province that has a high risk of the tsunami disaster. Based on the 2016-2020 Aceh Disaster Risk Study [3] in Lhoseumawe City 6,032 people were exposed to the tsunami disaster. The number is spread along the coast in the city of Lhokseumawe. A tsunami disaster is a disaster that takes the most lives and causes damage in a short time so that the paradigm of responsive disaster management must be changed to a preventive activity, namely disaster risk reduction [4]. One way to reduce disaster risk is preparedness. This preparedness will help the community, especially the school community, in planning what actions need to be taken in the event of a disaster.

\section{Theoretical Framework}

\subsection{Tsunami Disaster}

Tsunami comes from the Japanese language, namely "tsu" which means harbor, and "nami" which means wave. Both

\footnotetext{
* Corresponding author: whenyutari@unimal.ac.id
} 
words mean "big waves in the harbor". So in the simplest terms, a tsunami is a series of ocean waves that are generally often caused by violent movements on the seabed. Tsunamis are included in the ranks of the most complex and frightening physical phenomena. The tsunami was responsible for the huge loss of life and property destruction. Because of its ferocity, the tsunami had a significant impact on the humanitarian, social, and economic sectors of society [5].

The speed of a tsunami is determined by the depth of the water. In deep water, a tsunami can travel at speeds of 500 to 1000 kilometers per hour while in shallow waters the speed slows down to several tens of kilometers per hour. In addition to speed, the height of the tsunami also depends on the depth of the waters [6]. Some tsunamis, and nearly all tsunamis that travel across the ocean floor with destructive force, are caused by subductions beneath the ocean floor associated with major earthquakes [7]. In Indonesia, on average, earthquakes occur 15 times a day in all parts of Indonesia, causing a tsunami to frequently hit Indonesia. From 1600 until now, there have been 109 tsunamis in Indonesia. Even in the last fifteen years, the tsunami occurred on average once every two years. However, the recurrence of a tsunami in every place takes place over a long period [8].

Sumatra and Java are the most vulnerable islands to tsunamis because they lie directly in front of the IndoAustralian Plate [9]. One of the cities on the island of Sumatra that has a moderate to high risk of a tsunami disaster is Lhokseumawe City. This can be seen in the Tsunami Disaster Risk Map in Lhokseumawe City issued by BNPB.

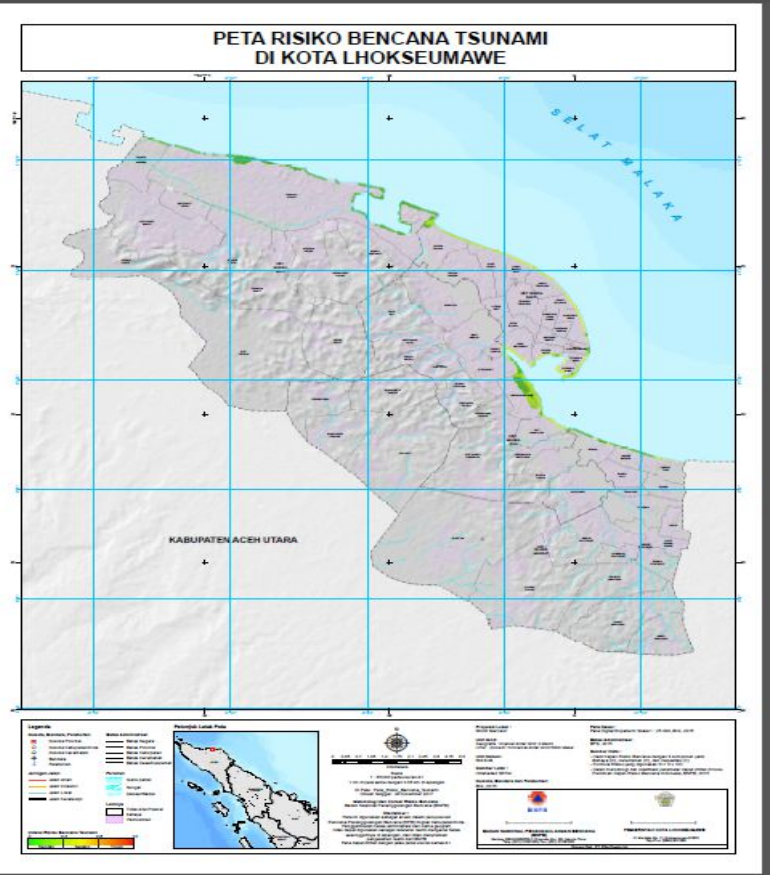

Fig. 1. Tsunami Disaster Risk Map in Lhokseumawe City.

Based on Fig. 1, it can be seen that the city of Lhokseumawe has a moderate to high tsunami risk index. This has become the basis for the Lhokseumawe community, especially the school community located on the coast, to increase preparedness in dealing with the tsunami disaster.

\subsection{Preparedness}

\subsubsection{Definition of Preparedness}

Preparedness is an effort made to get a better preparation to deal with existing disaster risks, including understanding and analyzing the relationship between threat risk and vulnerability and then using knowledge to take action to reduce the impact of disasters. Disaster preparedness is one of the dimensions in disaster management that is often associated with actions that enable individuals and communities to respond quickly and effectively to the event of disaster [10]. The change from responsive to preventive paradigm emphasizes that disaster preparedness is one of the important stages to reduce the number of losses that arise due to disasters. Preparedness is one part of disaster risk reduction which is in the period before a disaster occurs or non-disaster situations.

\subsubsection{Aspects of Preparedness}

Several aspects that require attention in the development of preparedness [11], namely:

1. Planning and organization: directives and policies related to planning for handling emergencies that are effective and continuously updated, as well as an adequate organizational structure for a response.

2. Resources: a complete inventory of all organizational resources, division of tasks and responsibilities

3. Coordination: strengthening coordination between institutions or organizations as well as eliminating friction and increasing cooperation between related institutions or organizations.

4. Readiness: disaster management organizational unit must be fully responsible for monitoring and maintaining preparedness standards for all elements.

5. Training and public awareness: the need for adequate training and public awareness and availability of accurate information.

In the analysis of this study, researchers used standard parameters to measure the preparedness of school communities according to LIPI - UNESCO/ISDR [11], namely: (1) Knowledge and Attitudes towards Disaster Risk; (2) Policies and Guidelines Relating to Preparedness to Anticipate Natural Disasters; (3) Plans for natural disaster emergencies; (4) Disaster warning system; (5) Mobilization of resources.

These five parameters are used to measure the preparedness of the school community. The preparedness study divides disaster preparedness stakeholders into 2 , namely the main stakeholders and supporting stakeholders. Stakeholders included in the main stakeholder groups, namely: (1) Individuals and households; (2) Government and (3) School Community, while supporting stakeholders, namely: (1) Community institutions, such as PKK, youth organizations, taklim councils, KAN, mosque/church youth; (2) Non- 
Government Organizations (3) Professional groups (4) Private parties [11]. This study will focus on the preparedness of the school community which is divided into three namely school preparedness as an institution (S1), teacher preparedness (S2), and student preparedness (S3).

\section{Research Method}

This research is descriptive quantitative research utilizing the survey method. The survey was conducted using a closed questionnaire and using instructions for filling out. There are three series of questionnaires in this study, namely the S1 (school administrators), S2 (teachers), and S3 (students) questionnaires. The content used in the questionnaire refers to the preparedness study conducted by LIPI - UNESCO/ISDR [11], to assess the level of preparedness of the school community in dealing with disasters. The focus of this research is aimed at five things, namely the level of knowledge and attitudes, policies and guidelines, emergency planning, warning systems, and resource mobilization. The sampling technique used in this study is the purposive sampling method. The criteria used are under the research objectives, namely the distance of the school to the beach or the vulnerability of the school to the tsunami disaster. Based on the needs of the study, State Elementary School 5 Lhokseumawe, State Elementary School 9 Banda Sakti, State Junior High School 5 Lhokseumawe, and State Vocational High School 2 Lhokseumawe was selected.

In this study, preparedness was measured using preparedness index analysis. The index numbers in this study include all indices for each parameter, namely knowledge and attitude (KA); emergency planning (EP), Warning System (WS), and Resource Mobilization Capacity (RMC) at each source. The higher the index number, the higher the level of preparedness of the school community. After knowing the parameter index value of one respondent, be it students, teachers, or schools, the index value of the entire sample can then be determined.

\section{Result and Discussion}

School community preparedness was measured based on filling out questionnaires from schools represented by principals (S1), teachers (S2), and students (S3). The schools selected based on the distance between the schools and the coastline were SD N 5 Lhokseumawe, SD N 9 Banda Sakti, SMP N 5 Lhokseumawe and SMKN 2 Lhokseumawe.

\subsection{Level of Knowledge and Attitude of School Community}

\subsubsection{Teacher}

Teacher knowledge about disasters is important in school preparedness. It is the teacher who will provide or pass on this knowledge to his students. So that students' knowledge about disasters depends on the knowledge of their teachers at school, although this knowledge can also be obtained from other media such as $\mathrm{TV}$, radio, and books. Based on the data obtained from the four schools as respondents, the level of knowledge and attitudes of teachers is included in the ready category, namely at index 67.

Utariningsih mentions that knowledge is the basis for carrying out the right activities in anticipating a disaster [4], $85 \%$ of teacher respondents know that earthquakes, tsunamis, floods, landslides, volcanic eruptions, and storms can cause disasters. Respondents also know the cause of the tsunami disaster even though they only know one cause, namely an earthquake under the sea. The questionnaire submitted was also about signs of a tsunami. Almost all respondents know that the signs of an impending tsunami are a strong earthquake that causes people to be unable to stand. The sign of an impending tsunami is not only an earthquake but also seawater that suddenly recedes, large waves on the horizon to a loud bang like an explosion. Only $20 \%$ of respondents knew all the signs of the tsunami.

Based on the data obtained, the knowledge about the tsunami disaster that was owned by the teachers was conveyed by $85 \%$ of the teachers. There are $20 \%$ of respondents who answered that they never talked about or were taught about the tsunami disaster. This can be caused by the lack of knowledge of teachers due to differences in teachers' educational backgrounds.

\subsubsection{Student}

Knowledge is the initial foundation of preparedness. A person will have an attitude of preparedness if they have good knowledge of the definition, types, signs, and ways to save themselves when a tsunami disaster occurs. Based on the data obtained, students' knowledge and attitudes have an index of 70.1 which is in the ready category. Knowledge about the tsunami disaster is the basis for awareness to carry out emergency planning, resource mobilization, and early warning [4]. Knowledge is also the basis for carrying out the right activities in anticipating a disaster. The basic question used to measure the parameters of knowledge and attitudes is the type of natural event that causes a disaster. $93 \%$ of the 84 respondents know that earthquakes, tsunamis, floods, landslides, volcanic eruptions, and storms can cause disasters. This shows that the respondents already know the basic concept of a disaster, namely hazard.

The data also shows that students' knowledge of tsunamis is already high. This is shown by $99 \%$ of respondents knowing that one of the causes of the tsunami disaster is an earthquake. This knowledge will be the capital for students in determining steps in the event of a tsunami disaster. This is because an earthquake is a natural warning for a tsunami disaster. The earthquakes, especially those that occur on the seabed, can cause a tsunami [7].

Knowledge about the causes of the tsunami disaster, which is an earthquake, is obtained from personal experience as well as the experience of people around the respondent. In 2004, Aceh was hit by a tsunami that 
caused nearly 200,000 deaths. The event began with an earthquake and receding seawater. Based on the data obtained, $83 \%$ of respondents know that the signs of a tsunami disaster are a strong earthquake and the seawater suddenly receding. $61 \%$ of respondents answered that when these signs occur, they should run away from the sea. In addition to gaining knowledge about disasters from experience, $81 \%$ of respondents answered that they gained knowledge from schools, print, and electronic media, as well as from books and television/radio. Among these media, the media that provides the most information to students about the tsunami disaster are radio and TV. This shows that the media, especially TV, plays an important role in increasing knowledge about disasters for both students and the general public.

Based on knowledge data from teacher (S2) and student (S3) respondents, the Knowledge and Attitudes index of School Community is:

$$
\begin{aligned}
& \text { KA Index }(\mathrm{KS}) \\
& \qquad \begin{aligned}
= & 0,60 * \mathrm{KA} \text { Index }(\mathrm{S} 2)+0,40 * \mathrm{KA} \text { Index }(\mathrm{S} 3) \\
& =0,60 *(67)+0,4 *(70,1) \\
& =68,24
\end{aligned}
\end{aligned}
$$

The level of knowledge and attitudes of the school community in Lhokseumawe City is in the category of ready with an index value of 68.24.

\subsection{School Community Policy and Guidance Level}

Since 2007, Indonesia has issued regulations on disaster management, namely Act no. 24 of 2007. Following up on this, the Ministry of Education and Culture developed a disaster risk reduction strategy in schools with teaching materials modules and training on integrating disaster risk reduction. The Ministry of Education and Culture has also issued Circular Letter $70 \mathrm{a} / \mathrm{MPN} / 2010$ on disaster risk reduction in schools. This circular letter became the reference for the provincial and city/district education offices in carrying out disaster risk reduction activities in schools.

In a survey conducted to four schools in Lhokseumawe, school leaders/teachers/staff were aware of regulations and circulars regarding disaster risk reduction in schools. This is indicated by an index value of 65 and is included in the ready category. Even though they are aware of the policy, only $50 \%$ of respondents have formed a disaster preparedness group at school. In addition, only $50 \%$ of respondents answered that they had integrated preparedness into relevant subjects at school and only $62 \%$ had included it in extracurricular skills. The implementation of rules by schools, which is quite far from optimal, is influenced by the budget. $50 \%$ of the respondents mentioned that they did not have a special budget for school preparedness, so the school had never carried out activities to increase preparedness such as increasing knowledge and skills and training in evacuation simulations in schools.

The less than the optimal implementation of school policies is one indication that schools are starting to forget the tsunami disaster that occurred in 2004. A disaster is a recurring event. In addition, the Lhokseumawe City tsunami risk index is in the medium to high category. Therefore, it is necessary to re-implement policies on disaster risk reduction in schools so that the preparedness of the school community in anticipating the tsunami disaster is increased.

\subsection{Level of School Community Emergency Planning}

\subsubsection{Teacher}

Data obtained from a sample of 4 schools, namely two elementary schools, 1 secondary school, and 1 high school in the city of Lhokseumawe show that the level of emergency planning for teachers in dealing with the tsunami disaster is still relatively unprepared. Based on the emergency planning questionnaire, an index of 44 was obtained which was at the level of being unprepared. The data obtained shows that all respondents have anticipated the occurrence of a tsunami disaster by preparing copies of the class documents/lessons taught. However, only 5\% of respondents have prepared several things to anticipate the tsunami disaster apart from preparing copies of documents. These include training students to save themselves, nailing/binding bookshelves to the wall, and placing heavy items on the floor.

Many school community activities are carried out in schools. Therefore, the preparedness of schools in anticipating the threat, especially the tsunami disaster, must be improved. Teacher preparation, when faced with disaster cases, is still low. $60 \%$ of teachers are only able to calm students down when a tsunami disaster occurs. When a tsunami occurs, teachers must be able to calm students down and guide students to immediately save themselves. However, $60 \%$ of respondents still do not know what they should do when it happens while teaching in class.

\subsubsection{Student}

The school community emergency planning parameter consists of 5 questions and an index value of 61.8 is obtained, which is in the almost ready category. Although $97 \%$ of respondents know that they need to save themselves when a tsunami occurs, the school does not support the evacuation route map. In addition, there are still many students, namely $27 \%$ of students who answered that they did not know what they should do to deal with the tsunami disaster. $92 \%$ said that they did not know an evacuation or rescue route. This is a problem because they are the ones who determine their safety in the event of a disaster. This is following a survey in Japan, in the 1995 Great Hanshin Awaji earthquake which showed that the percentage of survivors was caused by the actions of Self by 35\%, Family Members 31.9\%, Friends/Neighbors $28.1 \%$, Passersby $2.60 \%$, SAR Team $1.70 \%$, and others $0.90 \%$ [12]. 


\subsubsection{School}

The data obtained from the 5 questions on the questionnaire show that the school's emergency response plan index is still in the unprepared category with an index value of 27.5 . Although $75 \%$ have saved a copy of the data to anticipate the tsunami disaster, all respondents answered that there is no evacuation plan. The agreement on evacuation places, evacuation route maps, evacuation equipment/equipment as well as conducting evacuation training/simulation has not been carried out by all respondents.

Evacuation plan parameters are interconnected with other parameters. The knowledge possessed by students and teachers will be useless if it is not supported by evacuation facilities. If a tsunami disaster occurs during school hours, students/teachers will be confused about where they should save themselves because they have not done any evacuation training/simulation. In addition, this evacuation plan is also related to disaster warning parameters. Disaster warnings will be effective in helping the school community to save themselves when a disaster occurs if it is supported by the existence of evacuation sites, evacuation route maps, and training.

Based on the index obtained from the teacher (S2), student (S3) and school (S1) respondents, it can be calculated that the school community emergency planning index value is:

EP Index (KS)

$=0,61 * \mathrm{EP}$ index $(\mathrm{S} 1)+0,30 * \mathrm{EP}$ index $(\mathrm{S} 2)+0,09 * \mathrm{EP}$ index (S3)

$=0,61 * 27,5+0,3 * 44+0,9 * 61,8$

$=35,6$ (Unprepared)

The level of emergency planning for the school community in Lhokseumawe City is in the unprepared category with an index value of 35.6.

\subsection{Level of School Community Disaster Warning System}

\subsubsection{Teacher}

The level of teacher resource mobilization is at an index of 41 . The index is included in the unprepared category. The level of teacher resource mobilization is seen based on seven questionnaires. On the question of tsunami warning signs/warnings in their area, $80 \%$ know the traditional tsunami warning signs/methods/local agreements and the national tsunami system. Indonesia has built a tsunami early warning system or often called the Indonesia Tsunami Early Warning System (Ina TEWS). The Indonesian Tsunami Early Warning System (Ina TEWS) serves to warn of a tsunami shortly after a major earthquake occurs at sea. The warning will help people living on the coast to immediately save themselves from the tsunami disaster [4]

In case when the teacher hears tsunami warning signs/warnings while teaching, only $10 \%$ of the respondents answer that they will not panic, guide students to evacuation sites, and immediately monitor the truth of tsunami news from the competent authorities. Based on the answers from the respondents, $80 \%$ of the teacher respondents did not know the signs of canceling the tsunami warning or the sign or information that the situation was safe after the tsunami was declared by the BPBD or the local government.

\subsubsection{Student}

Students' knowledge of the tsunami warning system is still in the unprepared category, namely at index 31.8 . This can be seen in the question about tsunami signs, as many as $80 \%$ of respondents answered that they did not know the tsunami warning signs, both national and traditional warning systems. Early warning is a series of activities to give warnings as soon as possible to the community about the possibility of a disaster occurring in a place by the authorized institution [13]. This early warning system will notify people living in areas with a tsunami risk level to carry out the early evacuation. However, in this study, there are still many respondents who do not know about early warning even though $96 \%$ of respondents know what to do if there are signs of a tsunami danger, which is to stay away from the beach or run to a higher place.

\subsubsection{School}

The disaster warning index value for schools is still in the unprepared category, which is still below the number 40 . Almost all questions in the questionnaire are answered with statements stating that there are none and have not been implemented by the school. Although schools have used a bell to signal the start/end of lessons, this bell has not yet been set by the school to be used as a broad disseminator of tsunami warnings in schools. In terms of disaster warning parameters, none of the schools that were sampled had the tools used for tsunami warnings.

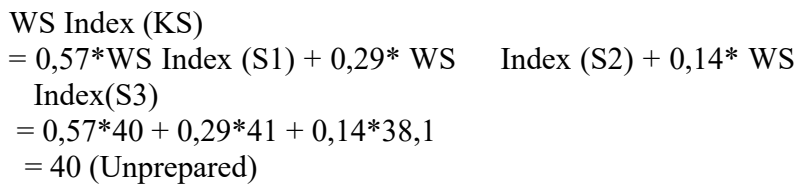

The level of the school community disaster warning system in Lhokseumawe City is in the unprepared category with an index value of 40 .

\subsection{Level of School Community Resource Mobilization}

\subsubsection{Teacher}

The level of mobilization of teacher resources in the city of Lhokeumawe based on data from 4 schools obtained an index number of 63. The index is in the almost ready category. On questions about whether or not they have attended training, workshops, seminars, lectures, discussions, or simulations, $70 \%$ of respondents answered that they have participated in disaster knowledge 
materials. Meanwhile, the material on early warning systems (equipment, sound signals, information dissemination) was only attended by $20 \%$ of respondents.

Knowledge about the tsunami disaster that was known by teacher respondents was conveyed by $85 \%$ of teachers to their students. The delivery is influenced by the educational background and the subjects taught by the teacher. However, $95 \%$ of teachers have never practiced disaster warning, first aid, and rescue/evacuation with their students.

\subsubsection{Student}

The level of mobilization of school community resources in Lhokseumawe City is still in the unprepared category, which is at an index of 40.5 . The index is obtained from 2 questions about activities related to disasters that the respondents have participated in. Based on the data obtained, all respondents answered that they had never conducted disaster evacuation simulation training. This indicates that the school community in Lhokseumawe, as illustrated by the 4 educational institutions sampled in this study, has not optimally prepared for the tsunami disaster. Although students' knowledge of tsunamis is categorized as ready, evacuation training/simulation needs to be carried out so that students' preparedness in dealing with tsunami disasters increases. This needs to be done because Lhokseumawe is a coastal area that is in the moderate to a high category for tsunami disasters.

\subsubsection{School}

The mobilization of school community resources has an index score of 52 and is in the almost ready category. $75 \%$ of schools already have a School Health Unit, Scouts and First-aid trained students that can be used for school preparedness in dealing with disasters. However, only $25 \%$ of teachers/school staff have attended workshops/seminars about disaster knowledge, evacuation plans, first aid, early warning systems, and evacuation simulations.

Regarding the policy parameters, namely Circular Letter 70a/MPN/2010 from the Ministry of Education on mainstreaming disaster risk reduction in schools, only $25 \%$ of respondents have included preparedness materials in the relevant lesson materials. This can happen because there is no regulation from the local office for the implementation of the circular letter. The teacher's knowledge and the absence of guidance can also be the cause of the non-implementation of the circular letter. $62.5 \%$ of respondents answered that they had never received assistance/guidance related to preparedness.

Based on the analyzed data, the level of mobilization of school community resources is as follows:

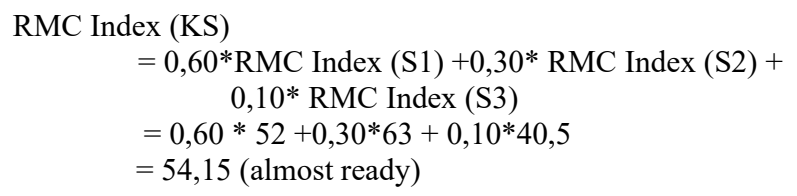

Based on the index value of 54.15, it can be seen that the level of mobilization of school community resources in Lhokseumawe City is in the almost ready category.

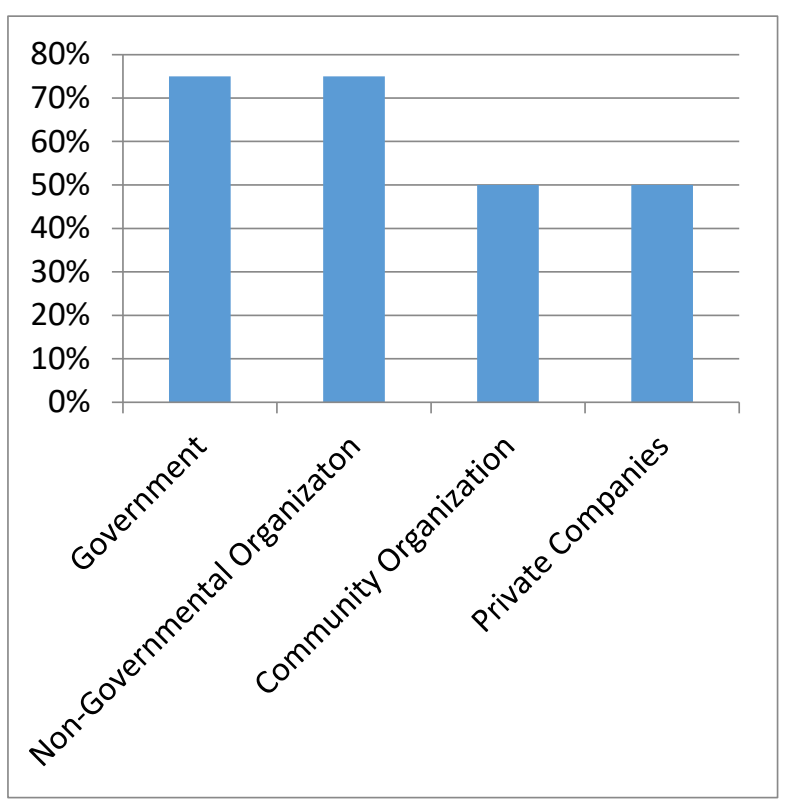

Fig. 2. Source of Aid/Guidance Related to Tsunami Disaster Preparedness

\subsection{School Community Preparedness Level}

A tsunami disaster is a type of disaster that can cause damage and loss of life. There is no tool to predict when a tsunami will occur. Therefore, it is necessary to carry out preventive activities. One of its important activities is to increase community preparedness for people who may be vulnerable to tsunami disasters. This study focuses on the preparedness of the school community in Lhokseumawe City. Based on the survey conducted, index numbers have been obtained for each parameter. The index values per community are as follows:

\subsubsection{School Index (S1)}

The school index value is a combination of the index value of school preparedness policy (PS), emergency response plans (EP), disaster warning (WS), and resource mobilization (RMC). The parameter index values are then added up according to their respective weights [11]. The following is the calculation of the school preparedness index value.

$$
\begin{aligned}
& \text { School Index }(\text { S1) } \\
& \quad=0,29(\text { PS Index })+0,41(\text { EP Index })+0,12(\text { WS Index }) \\
& +0,18(\text { RMC Index }) \\
& =0,29(65)+0,41(27,5)+012(4,1)+0,18(52) \\
& =30,6
\end{aligned}
$$

Based on the sum of the index values of the school preparedness policy parameters (PS), emergency response plans (EP), disaster warnings (WS), and resource mobilization (RMC), school preparedness is in the category of unprepared with an index value of 30.6. 


\subsubsection{Teacher Index (S2)}

The teacher index value is a combination of the index values of knowledge about disasters (KA), emergency response plans (EP), disaster warnings (WS), and resource mobilization (RMC). The parameter index values are then added up according to their respective weights [11]. The following is the calculation of the teacher preparedness index value.

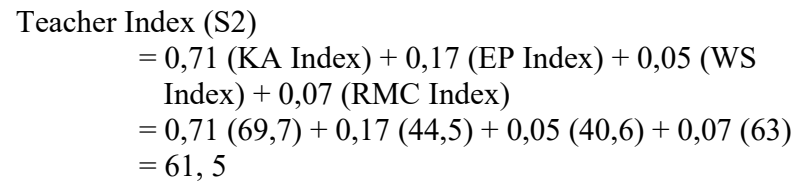

Based on the sum of the index values for disaster knowledge (KA), emergency response plans (EP), disaster warnings (WS), and resource mobilization (RMC), the level of teacher preparedness are in the almost ready category, with an index value of 61.5.

\subsubsection{Student Index (S3)}

The student's index score is a combination of the index values of the knowledge about disasters (K), emergency response plans (EP), disaster warnings (WS), and resource mobilization (RMC). The parameter index values are then added up according to their respective weights [11], The following is the calculation of the student preparedness index value.

$$
\begin{aligned}
& \text { Student Index }(\mathrm{S} 3) \\
& =0,83(\text { KA Index })+0,08(\text { EP Index })+0,04(\mathrm{WS} \\
& \quad \text { Index })+0,04(\text { RMC Index }) \\
& =0,83(70)+0,08(61,9)+0,04(31,8)+0,04(40,5) \\
& =65,9
\end{aligned}
$$

Based on the sum of the index values for disaster knowledge (KA), emergency response plans (EP), disaster warnings (WS), and resource mobilization (RMC), the level of preparedness of students are in the ready category with an index value of 65.9 .

The level of preparedness is the combined result of the school community knowledge index, the school community emergency planning index, the school community disaster warning system index, the school community policy, and guidance index, and the school community resource mobilization index using each weight in each parameter.

Total KS Index

$$
\begin{aligned}
= & 0,50 * \text { KA Index }(\mathrm{KS})+0,10 * \text { PS Index }(\mathrm{KS}) \\
& +0,23 * \text { EP Index }(\mathrm{KS})+0,07 * \text { WS Index } \\
& (\mathrm{KS})+0,10 * \mathrm{RMC} \text { Index }(\mathrm{KS}) \\
= & 0,50 * 68,24+0,10 * 65+0,23 * 35,6+ \\
& 0,07 * 40+0,10 * 54,15 \\
= & 57,02
\end{aligned}
$$

After summing up using their respective weights following the guidelines from LIPI-UNESCO [11], the school community preparedness index value in
Lhokseumawe City is 57.02 which is in the almost ready category. The index value of each parameter can be seen in Fig. 3.

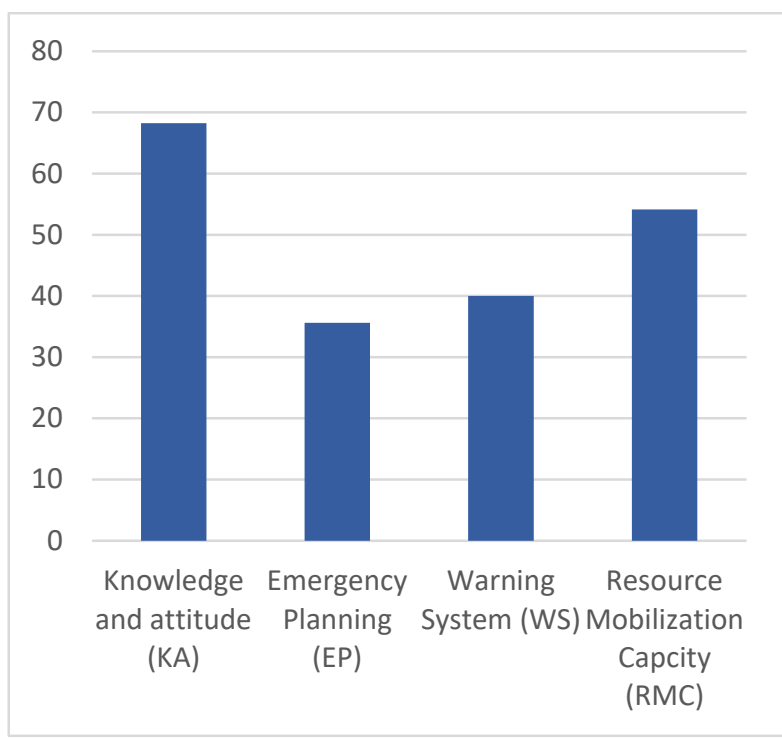

Fig. 3. Index Values for Each Parameter of School Community Preparedness

\section{Conclusion}

- The level of knowledge and attitudes of the school community in Lhokseumawe City is in the ready category with an index value of 68.24 .

- The level of school community policies and guidelines is in the ready category with an index value of 65 .

- The level of emergency planning for the school community in Lhokseumawe City is in the unprepared category with an index value of 35.6.

- The level of the school community disaster warning system in Lhokseumawe City is in the less ready category with an index value of 40 .

- The level of mobilization of school community resources in Lhokseumawe City is in the almost ready category with an index value of 54.15.

- The level of preparedness of the school community in the city of Lhokseumawe is in the almost ready category with an index value of 57.02 .

\section{References}

1. BNPB, Aceh Province Natural Disaster in December 2004 (DIBI, BNPB, 2021)

2. BAPPENAS, Preliminary Damage and Loss Assessment (Badan Perencanaan Pembangunan Nasional, 2005)

3. BNPB, Aceh Disaster Risk Assesment 2016-2020 (BNPB, Jakarta, 2016)

4. W. Utariningsih, R. Sofia, Journal SPATIAL Wahana Komunikasi and Informasi Geografi, 20, 2227 (2020)

5. UNESCO-IOC, Tsunami Glossary:IOC Document Information No.1221 (UNESCO, Paris, 2006) 
6. T. Puspito,Nanang, Managing Disaster Risk in Maritime Areas ( ITB, Bandung, 2010)

7. Dudley, W.C, Min L. Tsunami ! (Pakar Raya, Bandung, 2006)

8. E. Yulianto, F. Kusmayanto, N. Supriyatna, Dirhamsyah. Surviving the Tsunami Disaster, Learning from the Tsunami in Aceh and Pangandaran (JTIC-UNESCO House, Jakarta, 2008)

9. A. Y. Baeda, F. Husain, Journal Teknik Sipil Institus Teklogi Bandung, 19, 1 (2012)
10. J. Sutton, K. Tierney, Disaster Preparedness: Concept, Guidance, and Research (University of Colorado, 2006)

11. LIPI-UNESCO/ISDR. Study of Community Preparedness in Anticipating Earthquake and Tsunami Disasters (LIPI, Jakarta, 2006)

12. BNPB, Disaster Preparedness Training Manual: Building Awareness of Alertness and Preparedness in Facing Disasters (BNPB, Jakarta, 2017)

13. W. Utariningsih, Disaster Management (Sefa Bumi Persada, Lhokseumawe, 2020) 